\title{
Repossession and the Democratization of Credit*
}

\author{
Juliano J. Assunção \\ PUC-Rio \\ Efraim Benmelech \\ Harvard University and NBER \\ Fernando S. S. Silva \\ PUC-Rio
}

* We thank Daron Acemoglu, Daniel Carvalho, Lauren Cohen, Ken French, Simon Gervais, Karl Diether, Todd Gromley, Oliver Hart, Campbell Harvey, Bengt Holmstrom, Laura Jones Dooley, Rafael La Porta, Marco Pagano, Manju Puri, Adriano Rampini, David Robinson, Andrei Shleifer, Matthew Slaughter, Jeremy Stein, Vish Vishwanathan, Amir Yaron, Rebecca Zarutskie, and seminar participants at Banca d'Italia, Brigham Young University, Boston University, The Chinese University of Hong Kong, Dartmouth (Tuck), Duke (Fuqua School of Business), Einaudi Institute for Economics and Finance, European Central Bank, the Grossman and Hart at 25 conference at the Solvay Brussels School of Economics and Management, Harvard-MIT Applied Theory seminar, HEC Paris, INSEAD, Pontifcia Universidade Católica do Rio de Janeiro,University of Southern California (Marshall), and Wharton for very helpful comments. Benmelech is grateful for financial support from the National Science Foundation under CAREER award SES-0847392. Assunção is grateful for financial support from the Consortium on Financial Systems and Poverty at University of Chicago and CNPq. Silva is grateful for financial support from CAPES and CNPq.

Juliano J. Assunção, Department of Economics, PUC-Rio. E-mail: juliano@econ.puc-rio.br. Efraim Benmelech, Department of Economics, Harvard University, Littauer Center, Cambridge, MA 02138. E-mail: effi_benmelech@harvard.edu. Fernando S. S. Silva, Department of Economics, PUC-Rio. E-mail: fernandosssilva@yahoo.com.br. 


\title{
Repossession and the Democratization of Credit
}

\begin{abstract}
We exploit a 2004 credit reform in Brazil that simplified the sale of repossessed cars used as collateral for auto loans. We show that the change has led to larger loans with lower spreads and longer maturities. The reform expanded credit to riskier, low-income borrowers for newer, more expensive cars. Although the credit reform improved riskier borrowers' access to credit, it also led to increased incidences of delinquency and default. Our results shed light on the consequences of a credit reform, highlighting the crucial role that collateral and repossession play in the liberalization and democratization of credit.
\end{abstract}




\section{Introduction}

Perhaps the most important legal feature of debt contracts is the lender's right to repossess assets when borrowers default on promised payments. The legal right to repossess collateral is critical to the provision of credit because it allows creditors to recover, at least partially, the value of their loans. We show how a 2004 credit reform that simplified the selling of repossessed cars led to the liberalization of the auto loan credit market in Brazil. Our evidence suggests that the legal change has led to larger loans with lower spreads, longer maturities, and higher leverage.

The development of the Brazilian auto loan market has faced several impediments. Chief among them was the inefficient process of repossession and resale of autos when borrowers defaulted on their loans. Banks were allowed to repossess the autos of borrowers who failed to repay their loans. However, these banks could not resell these repossessed cars without court approval. As a result, the time from repossession of a car to its resale by the bank averaged more than two years. In August 2004, the Brazilian government announced a broad credit reform that, among other legal changes, eased the resale of repossessed autos.

Although previous research has analyzed some implications of legal reforms to credit markets, the evidence on the effect of such reforms on lending is mixed. While the improvement in judicial efficiency and creditor rights is correlated with increased supply of external finance (Jappelli, Pagano, and Bianco (2005), La Porta et al. (1997), Laeven and Majnoni (2005)), the effect of the reform on financial contracts is ambiguous. On one hand, increased recovery of collateral induces banks to offer larger loans with lower credit spreads and longer maturities. On the other hand, however, increased recovery rates enables riskier borrowers who were previously rejected and rationed out of the market to obtain credit. While enhancing the ability of banks to recover their loans leads to better contracts for existing borrowers, banks will offer smaller loans, with higher credit spreads and shorter maturities, to the newly admitted cohort of riskier borrowers.

We use micro-level data from one of the largest banks in Brazil to provide direct evidence on the consequences of the reform. Our data enable us to separate the direct effect of the legal change on contracts from the composition effect that results in increased lending to riskier borrowers. We show that the reform brought about an expansion of credit, enabling riskier, low-income borrowers to obtain loans and purchase newer, more expensive cars. We refer to this effect as the "democratization of credit," in which the strengthening of the ability of lenders to foreclose, repossess, and 
sell assets increases the supply of credit to those who need it most.

Using detailed information on a large sample of auto loans made by one of Brazil's largest banks during the years 2003 to 2005 we study the relation between the bank's ability to seize and resell collateral and a battery of outcomes pertaining to: (i) financial contracts, (ii) borrower characteristics, (iii) car characteristics, and (iv) loan performance. Consistent with the predictions from the financial contracting literature (Hart and Moore (1994), Shleifer and Vishny (1992)), our analysis shows that the credit reform in Brazil led to larger loans with lower spreads, longer maturities, and higher leverage.

We also find that the ability to resell collateral affected not only financial contracts but also the composition of borrowers in the auto loan market. As the process of reselling repossessed cars was expedited dramatically with the implementation of the reform, expected loss given default from a car loan declined sharply. As a result, borrowers with a higher probability of default would be expected, ex ante, to be more likely to obtain an auto loan. Our regression analysis shows that the reform enabled riskier, low-income borrowers to obtain loans and purchase newer, more expensive cars. Further, borrowers who are self-employed were more likely to obtain a car loan. These results demonstrate a process of the "democratization" of credit - in which an improved legal process to resell collateral led to an expansion of credit to borrowers who were less likely to obtain a loan before the reform.

Further, we study the consequences of the reform for loan performance. A growing body of empirical evidence suggests that credit expansion leads to subsequent waves of default and repossession (Keys et al. (2010), Mian and Sufi (2009, 2010)). Given that we find that the reform led to lending to riskier borrowers, it is likely that loans granted after the reform will have a higher rate of default. We use three measures to capture the performance of loans: (i) late payment, (ii) default on one loan installment, and (iii) default on the entire loan. We find that after controlling for contract terms, personal and car characteristics, macro controls, and time trend, the likelihood of a late payment and default increased after the law was implemented. The effect of the reform on the probability that the borrower will be late or default is substantial, implying an increase of about $20 \%$ relative to the mean.

Our regressions control for a battery of contract, borrower, and car characteristics, in addition to macro variables. Although our identification strategy hinges on the notion that our results are driven only by the time-series change in the law, other important polices that affect credit markets 
also change over time and potentially coincide with our time-series measure of the reform. Although our analysis controls for such macro variables as the federal funds rate, inflation, and GDP growth, it is possible that unobserved contemporaneous shocks affected car loans through channels other than the law.

To alleviate concerns about the validity of our identification strategy we add a cross-sectional dimension to the analysis by utilizing information on the age of the car underlying the loans. Some asset types such as cars are subject to an accelerated depreciation in which they lose more of their value upfront. Whereas the legal reform applies to all auto loans, we expect loans on new cars to be affected more than those backed by older cars. While before the reform it took about two years to resell a repossessed car regardless of its age, a newer car can be expected to lose more of its collateral value earlier on, which should affect the terms of loans secured by new cars more than those secured by used autos. Consistent with this prediction, we find that the effect of the reform on credit spreads is higher for new cars compared to used cars. We obtain similar results for each of the other dimensions of the contract. The law prolonged loan maturities and increased loan amounts for new cars while having a smaller effect on loans secured by used cars.

Our paper adds to the growing literature on the role that creditor protection plays in the development of credit and debt markets (e.g., Djankov, McLeish, and Shleifer (2007), Haselmann, Pistor, and Vig (2010), La Porta et al. (1997, 1998), and Vig (2011)) and in shaping financial contracts (e.g., Bae and Goyal (2009), Kaplan, Martel, and Stromberg (2007), Lerner and Schoar (2005), and Qian and Strahan (2007)). Our paper is also related to the vast theoretical literature on the role of collateral in secured lending (Aghion and Bolton (1992), Bolton and Scharfstein (1996), Boot and Thakor (1991), Eisfeldt and Rampini (2009), Hart and Moore (1994, 1998), Johnson and Stulz (1985), and Rampini and Viswanathan (2010)) and to the empirical evidence on the effect of collateral on financial contracts and lending (Benmelech (2009), Benmelech, Garmaise, and Moskowitz (2005), Benmelech and Bergman (2008, 2009, 2011), Berger and Udell (1990), Jimenez, Salas, and Saurina (2006), John, Lynch, and Puri (2003), and van Binsbergen, Graham, and Yang $(2010))$.

The rest of the article is organized as follows: Section II describes the institutional details of the credit reform in Brazil. Section III describes of our data sources and summary statistics. Section IV presents the empirical analysis. Section V concludes. 


\section{Institutional Details}

\section{A. Background}

The development of the Brazilian auto loan market has faced several impediments. Chief among them was the inefficient process of repossession and resale of autos when borrowers defaulted on their loans. Brazilian banks could repossess the autos of borrowers who failed to repay their loans. Without court approval, however, banks could not resell these repossessed cars. As a result, the time from repossession of a car to its resale by the bank averaged more than two years. In August 2004, the Brazilian government announced a broad credit reform that, among other legal changes, eased the resale of repossessed autos. ${ }^{1}$

The reform dramatically changed the auto loan market. In 2007, Veja, the most popular weekly newsmagazine in Brazil, wrote:

Brazilians have never bought so many cars. In 2007, it will be 2.5 million units, an unparalleled record for the auto industry. ... And there is only one explanation for this: credit. Until recently, in Brazil, credit was scarce and expensive. Now, it is possible to buy a car without a down payment and to finance it for up to seven years with installments below the (monthly) minimum wage. ${ }^{2}$

Before the credit reform, auto financing was not an attractive line of business for banks due to the inefficient legal process in the event of default. The credit reform transformed the auto loans market, as Veja noted:

The proceedings dragged on for years, and often the judges gave cause to buyers. This situation changed only after the implementation of the "lei de alienação fiduciária," a legal institute that provides for the rapid recovery of car financing in case of default.

To better understand the changes in the credit market, we first describe the auto credit system before the reform.

\section{B. The Brazilian Auto Loan Market}

We briefly describe the process of obtaining an auto loan in Brazil before moving to the details of the credit reform. Buyers who need to finance the purchase of a vehicle typically fill out a loan

\footnotetext{
${ }^{1}$ One of the government's official objectives was to reduce costs associated with the recovery rates of auto loans.

2 "Propulsão a Crédito," Veja, October 31, 2007.
} 
application through an auto dealer. The loan is then submitted for bank review and approval. If the bank approves the application the dealership handles the loan agreement but is not held liable for the loan. Auto loans can be granted either through "crédito direto ao consumidor" (direct consumer credit) or "arrendamento mercantil." Both procedures are similar, and in both cases the purchaser gains ownership of the vehicle only after having fully repaid the loan. Loans are amortized and typically mature in three years, with equal monthly installments. If the borrower defaults on three consecutive payments, the bank issues a report to both the Central Bank of Brazil and the country's largest credit agency, Serasa. ${ }^{3}$ The bank may then either attempt to renegotiate the loan or trigger the repossession process.

\section{The Credit Reform}

Brazilian fiduciary law applied first to capital markets and was later extended to auto and mortgage loans. ${ }^{4}$ According to the law, the bank, after granting an auto loan, holds the title to the car until the loan is paid in full. The borrower is entitled to the daily use of the vehicle used as collateral. When the borrower pays all loan installments in accordance with the agreement, the bank transfers the car title to the borrower. In the case of default, the borrower may no longer use the car. The bank can then repossess the vehicle through a court injunction after proving default. Before the reform, however, the bank needed to wait for a court decision in order to resell a repossessed car. During this period the car was stored at a parking facility.

Initial implementation in the 1960s proceeded smoothly. The legal process was fairly short, and the court system could handle the number of cases awaiting trial. Over time, however, the process lengthened. By the late 1990s financial institutions faced lengthy waits for authorization to resell repossessed vehicles. According to a senior Brazilian bank officer, in many cases banks had to wait more than three years. The inefficient legal system also hurt borrowers. During the time it took to resell cars, borrowers' indebtedness increased at the pace of the loan interest rate while the value of the underlying collateral, the car, depreciated over time.

The need for reform was indisputable. To remove inefficiencies in the auto loan and other credit markets, the government enacted federal law n.10.931/04, the Lei de Alienação Fiduciária (fiduciary law), which the president signed on August 2, 2004. This legislation, which became effective on its

\footnotetext{
${ }^{3}$ Serasa is a private bureau. Its role is to maintain a database on the standing of borrowers.

${ }^{4}$ The law was implemented in 1965; it was extended to auto loans in 1969 and to mortgages in 1997.
} 
enactment, affected the auto loan, mortgage, and capital markets. Due to political uncertainty, the banking system was skeptical about the implementation of the law until it was enacted. There was also considerable uncertainty about the ability of the court system to operationalize the reform.

The most notable changes introduced by the law that apply to the auto loan market regard the authorization to resell a repossessed vehicle. This process became simpler and faster. Amendolara (2006) highlights three differences regarding the process of auto repossession and resale. First, after the bank gets a court injunction to seize the car, the borrower has five days to pay the debt in full and recover possession of the vehicle. Second, the borrower has fifteen days to challenge the court injunction instead of the previously established three days. The main difference in the law here is that now the bank may resell the car after this period of fifteen days, where previously it could sell the car only after trial. Third, the borrower has the right to challenge the bank in court. If the bank is found guilty, it must compensate the borrower by an amount equal to 150 percent of the total loan.

Ultimately, the law has reformulated relationships among borrowers, creditors, and courts. Borrowers and creditors now engage in direct relationships, and courts play a significant role only when borrowers explicitly request it. The law avoids unnecessary trials, reduces the reliance on courts, and increases the enforceability of auto loan contracts.

The new environment marked a dramatic turn for the auto loan market. According to senior officers from a large Brazilian bank, the process of repossession and resale formerly took between two and three years. Now this process takes three weeks. Although some borrowers sue the bank after losing their car, the bank has never been found guilty by the courts. Finally, the supply of credit for auto loans has grown dramatically. According to the Central Bank of Brazil, credit for vehicles grew from $\mathrm{R} \$ 34.7$ billion (US $\$ 11.5$ billion) in August 2004 to $\mathrm{R} \$ 60.2$ billion (US $\$ 27.9$ billion) two years later.

\section{Data and Summary Statistics}

Our proprietary data come from one of the three largest private banks in Brazil. ${ }^{5}$ As of December 2010 the combined assets value of these banks - Bradesco, Itau Unibanco, and Santander - was $\mathrm{R} \$ 1.7$ trillion (US\$1 trillion). According to the Central Bank, Bradesco, Itau Unibanco, and Santander account for $43 \%$ of the Brazilian banking system, and their credit portfolio as of December

\footnotetext{
${ }^{5}$ We are unable to disclose the bank's name.
} 
2010 was $\mathrm{R} \$ 573$ billion (US $\$ 345$ billion). ${ }^{6}$ The bank that provided us with the data (hereafter "The Bank") plays a significant role in the car loan market, having a market share of more than $15 \%$ in 2003 , the first year of our data.

We obtained a random yet balanced sample of about 17,000 loan contracts covering the period from August 2003 to July 2005. Our data span an interval of the 24 months surrounding the implementation of the law. We chose this time frame in order to incorporate in the analysis the time needed by The Bank to better understand the law and adjust its lending practices to the new institutional setting. The symmetry of two equal periods of 12 months before and after the implementation of the law allows us to account for possible seasonal effects.

The dataset includes micro-level detailed information for each loan contract on contract terms, borrower's characteristics, and the cars against which the loans were made. The loan contract terms include credit spread (defined as the difference between the monthly interest rate on the loan and federal rate fund), maturity (in months), down payment (payment the borrower made out of pocket when buying the car), total financed (loan amount), and proportion financed (loan amount divided by car value). ${ }^{7}$ The data also contain a rich set of borrower characteristics, including consumer leverage, income, risk, gender, job, residence, and marital status. We also know whether the borrower has been a client of the bank in the past and whether the loan is guaranteed by a third party. Finally, the data also include information on the underlying car against which the loan was given. In particular, we know car model, year of manufacture, and whether a priority dealer made the sale. The Appendix provides detailed information on the definitions of the variables used here and their construction.

Table 1 displays descriptive statistics for the variables used in the analysis. As Panel A shows, the average spread is $1.10 \%$ per month with a standard deviation of 66 basis points per month. Loan maturity is around three years (36.1 months), with the 5th percentile being 18.0 months and the 95 th percentile 48.0 months. Down payments are sizable compared to car value. The average down payment is $\mathrm{R} \$ 6,903$ (US $\$ 2,448$ ), while the amount financed averages $\mathrm{R} \$ 9,760$ (US $\$ 3,461$ ). Borrowers finance, on average, $62.3 \%$ of car value. The mean consumer leverage - defined as the ratio of monthly loan installments to monthly income - is $24.9 \%$, and ranges between $8.0 \%$ (5th

\footnotetext{
${ }^{6}$ The public sector also plays a major role in the Brazilian banking system. For example, both the largest Brazilian bank, Banco do Brasil, and Caixa Economica Federal, the fourth commercial bank, are controlled by the federal government.

${ }^{7}$ All loans in the data are amortized to equal payments through the life of the loan.
} 
percentile) to $46.1 \%$ (95th percentile).

Panel B of Table 1 presents summary statistics of borrower characteristics. The median borrower's monthly income is $\mathrm{R} \$ 1,706$ (US $\$ 605$ ). There is a wide dispersion in borrowers' income, which ranges from a 5 th percentile of $\mathrm{R} \$ 803(\$ 284.8)$ to a 95 th percentile of $\mathrm{R} \$ 6,181(\$ 2,191.9)$. The Bank's clients represent $24 \%$ of the borrowers in the sample, and $8 \%$ of the contracts have a third-party guarantor. The Bank classifies borrowers into three categories, "high risk," "medium risk," and "low risk," where $3 \%$ of borrowers are classified as "high risk." About two-thirds of the sample consist of males; $40 \%$ are single, and $45 \%$ are married. Homeowners represent $83 \%$ of the borrowers, and $13 \%$ of the borrowers live with their parents. Among the borrowers, $59 \%$ are employees of firms, compared to $26 \%$ classified as self-employed or entrepreneurs and $12 \%$ identified as retired or as pensioners.

Panel $\mathrm{C}$ provides more information on the characteristics of the cars against which the loans are granted. There are two car characteristics. First, we define a dummy variable to indicate whether the car is new. Only $21 \%$ of the cars financed by The Bank are new. The mean car age is 5.32 years, and it ranges from new (5th percentile) to 13 years old (95th percentile). Second, The Bank classifies car dealers into two categories: priority and not priority. A dealer is considered a priority dealer if a low proportion of borrowers buying a car through the dealer default. In the sample, $88 \%$ of the cars were purchased from priority dealers.

Panel D reports summary statistics on three measures of loan outcomes. Late is a dummy equal to one if the borrower was late on a loan installment, and zero otherwise. Default installment is a dummy variable equals to one if the borrower was late on two installments at the same time, and zero otherwise. Whenever a borrower has been late for over 90 days the loan is considered to be in default. As Panel D demonstrates, the incidence of late payment and default happen in about 8 to 9 percent of the loans in our sample.

Finally, Panel E exemplifies the macro environment in Brazil during the period we study. As the Table shows, average monthly federal fund rates were $1.42 \%$, inflation rate was $8.92 \%$ and ranged from $5.89 \%$ to $15.14 \%$, and quarterly GDP growth was $1.15 \%$ on average. 


\section{Empirical Analysis}

In this section, we analyze empirically the effect of the law on a battery of loan terms, borrower characteristics, and loan outcomes. Starting with a simple univariate analysis, Table 2 reports for the main variables of interest summary statistics that are calculated separately for the periods before and after enactment of the law. As Panel A of Table 2 illustrates, average monthly credit spread declined from $1.18 \%$ to $1.02 \%$ after the law's enactment. Likewise, loan maturity increased from 34.6 to 37.7 months, down payments declined, and as a result the total amount financed (the size of the loan) increased, resulting in loans with higher loan-to-value ratios and consumers with increased leverage.

Similarly, Panel B reports summary statistics of borrower characteristics broken down by preand post-law periods. The key characteristics that changed in a statistically significant manner in the post-law period pertain to the borrowers' riskiness and employment status. According to Panel $\mathrm{B}$, borrowers in the post-law period were more likely to be high risk and to be self-employed or entrepreneurs than before the law was enacted.

The evidence in Table 2 suggests that enactment of the law led to larger loans with lower spreads and longer maturities as well as to expansion of credit to riskier borrowers. We turn now to regression analysis.

\section{A. The Legal Reform and Loan Terms}

We study the effect of an enhancement in creditor rights on spreads, loan maturity (in months), loan size, and consumer leverage by estimating the following equation:

$$
\text { loan characteristics }{ }_{i, t}=\alpha+\beta_{1} \times \text { law }_{i, t}+\mathbf{T}_{\mathbf{i}, \mathbf{t}} \lambda+\mathbf{b}_{\mathbf{i}} \psi+\mathbf{c}_{\mathbf{i}, \mathbf{t}} \theta+\mathbf{m}_{\mathbf{i}, \mathbf{t}} \xi+\mathbf{e}_{\mathbf{i}, \mathbf{t}} \gamma+\epsilon_{\mathbf{i}, \mathbf{t}}
$$

Where $l a w_{i, t}$ is a dummy variable indicating that the loan was initiated after the law was implemented. $\mathbf{T}$ is a vector of contract terms that includes spread, maturity, and down payment; $\mathbf{b}$ is a vector of borrower characteristics that includes income, risk, gender, a dummy equal to one if the borrower has a guarantor, type of job, type of residence, marital status, and whether the borrower is a bank client; $\mathbf{c}$ is a vector of car characteristics and includes a dummy variable equal to one if the car is new, a dummy indicating whether the borrower took the loan from a priority dealership, and the year in which the car was made; $\mathbf{m}$ is a vector of car model fixed-effects; and $\mathbf{e}$ is a vector 
of macro controls that includes the federal fund rate, inflation, GDP growth, and a time trend. ${ }^{8}$ The coefficient of interest is $\beta_{1}$, which measures the effect of the law on contract characteristics.

Panel A of Table 3 reports results from estimating the effect of the credit reform on spreads, maturity, loan size, and consumer leverage. Because debt contracts have several facets that are jointly determined, it is virtually impossible to estimate the simultaneous effect of the reform on each of these dimensions. Instead, we study each contractual term separately. Our regressions control for all contract terms (spread, maturity, and down payment) with the exception of the contractual term, which we use as a dependent variable. ${ }^{9}$ As the first column of Table 3 shows, the reform significantly decreased credit spreads charged by The Bank. Controlling for contract, borrower, and car characteristics as well as macro variables, we find that after the reform, credit spreads on car loans declined by 10.6 (127) basis points per month (year), representing a decline of $9.4 \%$ compared to the unconditional mean spread.

Moreover, as the second column shows, the reform prolonged the maturity of the loans by 2.07 months (statistically significant at the 1\% level), representing an increase of $6 \%$ relative to the unconditional average maturity before the law was enacted. These results are consistent with a recent A. T. Kearney report, which states that

automotive credit has grown at consistent rates over the past years. Outstanding volumes have risen from $R \$ 30$ Billion in 2003 to $R \$ 100$ Billion in 200\%. Average loan terms, which ranged from 24 to 36 months in the past, today are set, as a standard, at 60 months. More aggressive financial companies risk contracts of 72 or even up to 99 months. ${ }^{10}$

Column 3 shows that average loan size (defined as the natural log of the total amount financed) increased by about $2 \%$. Likewise, the last column of Table 3 reports the effect of the legal reform on consumer leverage. Leverage - defined as the ratio of loan installment to income - increases by 1.841 (7.5\% of the unconditional mean before enactment of the law) after controlling for other contract terms as well as personal and car characteristics and macro variables and year fixed-effects.

\footnotetext{
${ }^{8}$ Even though our results hold when we include year fixed-effects, we employ a time trend in order to utilize the variation in the 24 month surrounding the enactment of the law. In contrast, when we include year fixed-effects, we can identify only off of variation in the year 2004 .

${ }^{9}$ This approach is similar to Benmelech, Garmaise, and Moskowitz (2005) and Qian and Strahan (2007).

${ }^{10} \mathrm{http}$ ///www.atkearney.com/index.php/Our-expertise/financial-brazils-economic-risk-from-accentuated-growthin-auto-loans.html.
} 
As Table 3 demonstrates, the reform led to improvements in contractual terms by prolonging loan maturity, reducing credit spreads, and increasing loan amounts. Our results are consistent with previous empirical studies on the effects of collateral values and legal protection on different contracts dimensions (Benmelech, Garmaise, and Moskowitz (2005), Benmelech and Bergman (2009), and Qian and Strahan (2007)).

Our results so far rely on the assumption that, after controlling for contract, borrower, and car characteristics as well as macro variables, changes in the law over time affect the outcomes of interest. That is, the variable law captures only the effects of the reform. However, other important policies that affect credit markets change over time and potentially coincide with our time-series measure of the reform. Although our analysis controls for a time trend and for such macro variables as the federal fund rate, inflation, and GDP growth, it is possible that unobserved contemporaneous shocks affect car loans through channels other than the law.

To alleviate concerns about the validity of our identification strategy we conduct several placebo tests and find that our results are not driven by a time-trend that is unrelated to the enactment of the law. We define a "placebo law" dummy variable that takes the value of one for some arbitrary dates unrelated to the timing of the Lei de Alienação Fiduciária, and zero otherwise. Panel B of Table 3 reports results from such placebo regressions in which we define August 2007 as the placebo law month, where the placebo dummy equals one for the twelve months after the "law," and zero in the twelve months before August 2007. ${ }^{11}$ We choose this time-period since it does not overlap with the 24 months surrounding the law enactment period. If our results are driven by a trend of improvement in contractual terms we should expect further declines in spreads, prolongation of maturities, and increases of loan amounts and leverage over time. However, as Panel B demonstrates, loan spread increases slightly during this time period - the opposite of what should happen if our results were driven by an ongoing trend of contractual improvements. Moreover, none of the other variables - maturity, loan size, and consumer leverage - is affected by the placebo law in an economically or statistically significant manner.

Although the estimates in Table 3 show that average maturity has lengthened, it is unlikely that all contracts have increased by about two months; more likely, some contracts increased substantially while the maturity of others was not affected. We analyze the effect of the law on

\footnotetext{
${ }^{11}$ Although we have conducted several placebo regressions, we report only the August 2006-July 2008 regressions for brevity.
} 
loan maturity in more detail in Table 4. We run linear probability OLS regressions to study the effect of the law on the likelihood that loan maturity is (i) two years or more, (ii) three years or more, and (iii) four years or more. ${ }^{12}$ Panel A shows that the likelihood of longer-term loans with maturities exceeding two, three, and four years increased after enactment of the law. Thus, the law did not merely increase the maturity of the average loan but instead led to the creation of loans that are one or two years longer. For robustness, and similar to Panel B of Table 3, we run placebo regressions and show that the placebo law dummy does not explain the likelihood of longer-term loans (Panel B).

\section{B. Collateral and Loan Terms: Cross-Sectional Evidence}

We add a cross-sectional dimension to the analysis by utilizing information on the age of the car underlying the loans. Some asset types, such as cars, are subject to accelerated depreciation, in which they lose more of their value up front. Indeed, in the United States the Internal Revenue Service allows accelerated depreciation for newer cars, in which a larger fraction of the asset value can be deducted in the first two years of the car's life. Although the legal reform applies to all auto loans, we expect loans on new cars to be affected more than those backed by older cars. Whereas before the reform it took banks about two years to resell a repossessed car regardless of its age, a newer car is expected to lose more of its collateral value earlier on, which should affect the terms of loans secured by new cars more than those secured by used ones.

We stratify the sample based on car age and estimate regressions similar to the specification in equation 1. Panel A of Table 5 reports results based on a new/old car stratification while Panel B stratifies loans backed by used cars along a five-year age threshold. Similar to the previous specifications, we control for contract terms, borrower characteristics, car model fixed-effects, macro controls, and a time trend. The inclusion of car model fixed-effects enables us to isolate the pure effect of the car's age in our stratification because the analysis is based on within car-model variation. ${ }^{13}$

As the first two columns of Panel A show, the effect of the reform on credit spreads is higher for new cars compared to used cars. In a sample of 3,702 new auto loans, the coefficient of $\beta_{1}$ is -0.344 representing a decrease of $29.2 \%$ relative to the mean and is significant at the $1 \%$ level.

\footnotetext{
${ }^{12}$ We use a linear probability model instead of non-linear specifications because of the battery of fixed-effects that are included in the analysis and the problem of incidental parameters.

${ }^{13}$ Because we stratify by car age, we do not include it as a car characteristic in the regression.
} 
In comparison, $\beta_{1}=-0.027$ and is statistically insignificant in a sample of 13,645 loans that are secured by used cars. We obtain similar results for each of the other dimensions of the contract. The law prolonged loan maturity by 5.882 months for new cars, representing an increase of $17 \%$ compared to a more moderate increase of 1.594 months (4.6\% relative to the mean) in loans secured by used cars. The next two columns show that although the law increased loan size by $12 \%$ for new car loans, it had no effect on used car loans. Finally, the law led to higher leverage ratios for new cars compared to old cars (5.229\% compared to $1.114 \%)$.

We further stratify the data on used cars in Panel B, using five years as our stratification threshold. There are 5,299 used cars that are five years old or less and 8,346 cars that are older than five years. Consistent with the findings in Panel A, we find that loans secured by used cars that are up to five years old have lower spreads, longer maturities, bigger loans, and higher leverage compared to loans secured by older cars. Taken together, the evidence presented in Table 5 is consistent with the importance of the legal reform for collateral values and is unlikely to be driven by a mere improvement in the underlying economic environment.

\section{The Effect of the Law on Borrower Characteristics}

We next examine the effect of the law on borrower characteristics. We hypothesize that the law affected not only financial contracts but also the population of borrowers. ${ }^{14}$ Indeed, the summary statistics in Table 2 show that enactment of the law has led to an increase in the fraction of borrowers who are classified as high risk (from 0.02 to 0.04 , significant at the $1 \%$ level). The table also documents an increase in the share of borrowers who are self-employed or entrepreneurs, from 0.24 in the 12 months preceding the law to 0.29 in the 12 months after the law. As the process of reselling repossessed cars has been expedited dramatically with the reform, the expected loss given default from a car loan has declined sharply. We argue that by increasing collateral values, the law relaxes constraints in the ability of borrowers to pledge their car as collateral. As a result, borrowers with a higher probability of default will be more likely to obtain an auto loan. That is, we expect the bank to expand credit to riskier borrowers given that, in the event of default, the collateral is now more valuable.

Specifically, we test the effect of the law on the following borrower characteristics: (i) income,

\footnotetext{
${ }^{14}$ See Jappelli, Pagano, and Bianco (2005) for a formal model of the effect of judicial enforcement in credit markets on the composition of borrowers in the market.
} 
(ii) borrower risk, and (iii) whether the borrower is self-employed or an entrepreneur and hence may lack a stable income. We estimate the following regression:

$$
\text { borrower characteristic }_{i, t}=\alpha+\beta_{1} \times \text { law }_{t}+\mathbf{T}_{\mathbf{i}, \mathbf{t}} \lambda+\mathbf{b}_{\mathbf{i}} \psi+\mathbf{c}_{\mathbf{i}, \mathbf{t}} \theta+\mathbf{m}_{\mathbf{i}, \mathbf{t}} \xi+\mathbf{e}_{\mathbf{i}, \mathbf{t}} \gamma+\epsilon_{\mathbf{i}, \mathbf{t}}
$$

Where the vectors $\mathbf{T}, \mathbf{b}, \mathbf{c}, \mathbf{m}$, and $\mathbf{e}$ are defined as before and the coefficient $\beta_{1}$ captures the effect of the law on borrowers' characteristics. Table 6 presents the results.

The first column of Table 6 reports the effect of the law on the borrower's income. We define the dependent svariable as the natural log of monthly income. Given that in Column 1 we estimate a semi-log specification, the coefficient $\beta_{1}$ suggest that the monthly income of an average borrower is $3.2 \%$ lower after the reform - an effect that is robust to the inclusion of controls that pertain to contract terms as well as car and other personal characteristics, time-series-based macro controls, and a time trend. That is - consistent with our conjecture - the reform succeeded in extending car loans to lower-income borrowers who were otherwise constrained in their ability to borrow given low collateral values.

Next, we study the effect of the law on the risk profile of borrowers. Whereas our first measure of borrower's income is likely correlated with the risk of default, we now turn to a more direct measure of risk that is used by The Bank for credit analysis. We regress our measure for high-risk borrowers on the law dummy and the battery of control variables used before: contract terms, personal characteristics, macro controls, and a time trend. As the second column of Table 6 shows, $\beta_{1}=0.014$, indicating an increase in the proportion of high-risk borrowers among the population of borrowers after the reform. The economic magnitude of this effect is sizeable, representing an increase of $70.0 \%$ compared to the unconditional mean in the period before enactment of the law.

Finally, in the last column of the table we test whether the law has had an effect on the likelihood that a borrower is self-employed or an entrepreneur. We hypothesize that, given that The Bank can now put more weight on collateral in its credit allocation, it will have less need to rely on a stable source of income that is more typical for those employed by firms than for the self-employed. As Table 6 shows, and consistent with the evidence from the summary statistics in Table 2, we find that the reform had a significant effect on the likelihood that someone who is self-employed or an entrepreneur will be able to obtain a car loan from The Bank. The coefficient of the law dummy $\beta_{1}=0.051$ (significant at the $1 \%$ level) represents an increase of $21.3 \%$ compared to the unconditional mean in the period before the reform. 
Taken together, our results suggest that, after the reform, The Bank expanded financial services to higher-risk, lower-income borrowers. Moreover, The Bank was more likely to extend credit to self-employed borrowers. The evidence shows that improvement in creditor rights leads to better and broader access to finance. Our findings point to the importance of legal protection for creditors and are consistent with the ample evidence gained from cross-country regressions (Benmelech and Bergman (2011), Djankov, McLiesh, and Shleifer (2007), La Porta et al.(1997, 1998). As far as we know, this article is the first to provide evidence that stronger creditor rights lead to a "democratization of credit" - as lower-income, riskier borrowers were now granted a loan from The Bank.

\section{Changing Borrower Characteristics and Loan Terms}

The evidence in Table 6 clearly demonstrates that enactment of the law enabled The Bank to grant loans to borrowers who would have been previously rejected. In addition to improving loan terms by reducing spreads and increasing maturities and loan amounts, the law has also led to the provision of credit to riskier borrowers, which in turn leads to higher spreads, shorter maturities and smaller loan amounts. That is, the average effect of the law on contracts is masked by its effect on increasing the supply of credit to riskier borrowers.

In this section we study the differential effect of the legal reform on loan terms conditional on borrower characteristics. Given that the reform led to an influx of riskier, low-income borrowers, we stratify the data on measures of risk and income to evaluate the law's effect on contracts separately for each group. Panel A of Table 7 reports results based on risk stratification. We split the sample into borrowers with a credit score of 1 (low risk) and those with the highest level of risk (score of 3 ) and estimate separate regressions within each group. There are 12,623 individuals classified as low risk and 464 at the highest risk of default.

As the first two columns of Panel A show, the effect of the reform on credit spreads is higher for low-risk borrowers compared to high-risk individuals. In a sample of 12,623 loans to low-risk borrowers, the coefficient of $\beta_{1}$ is -0.117 , representing a decrease of $11.5 \%$ relative to the mean (significant at the $1 \%$ level). In comparison, $\beta_{1}=0.027$ and is statistically insignificant in the high-risk sample. Likewise, loan maturity increased by 1.991 months, representing an increase of $5.9 \%$ relative to the pre-law mean, while there is no statistically significant effect of the law on loan maturity of risky borrowers. The next two columns show that although the law increased loan size 
by $2.8 \%$ for low-risk borrowers, it had no effect on loans to high-risk individuals. Finally, the law led to higher leverage ratios for risky borrowers but had no effect on risky borrowers.

We conduct similar analysis in Panel B, comparing the differential effect of the law on the first and the fourth quartiles of income. Consistent with the evidence in Panel A, we find that for highincome borrowers $\beta_{1}$ is -0.173 , representing a decrease of $17.0 \%$ relative to the mean (significant at the $1 \%$ level). In comparison, for low-income borrowers $\beta_{1}=0.035$ and is statistically insignificant. Similar results are obtained for maturity and leverage in which the effect is higher for high-income borrowers, while we do not find a statistically significant effect of the law on the loan size of either high- or low-income borrowers.

\section{E. The Effect of the Law on Car Characteristics}

We now analyze the effect of the law on the type of car securing the loans. As shown in the previous section, the reform led to larger loans, lower spreads, and longer contracts and enabled lower-income, self-employed, and high-risk borrowers to obtain loans. We conjecture that the improvements in contractual terms may lead borrowers to choose newer, more expensive cars.

We report the results in Table 8 with odd columns showing results from regressions that include car model fixed-effects and even columns presenting results without car model effects. All regressions control for personal characteristics as well as macro variables and a time trend. Unlike our previous specifications we do not control for contractual terms. There is a strong correlation between loan maturity and car attributes such as car age and whether the car is new, since newer cars are more likely to receive longer-term funding due to their durability. ${ }^{15}$ When we include loan maturity in the regressions, the effect weakens considerably both economically and statistically, suggesting that the effect of the law on the types of cars that borrowers purchase is through a contractual channel.

The first column of Table 8 displays the results from a regression in which the dependent variable is the log of car value. As Column 1 demonstrates, the value of cars financed by The Bank after the reform increased by $2.0 \%$ (significant at the $1 \%$ level). The estimate in Column 1 is a within model estimate since we control for car model fixed-effects. When we do not difference out car model effects, the coefficient is almost fourfold because it captures not only within-model price variation but also cross-car model variation due to borrowers shifting to more expensive model types.

\footnotetext{
${ }^{15}$ Benmelech (2009) documents similar effects for nineteenth-century American railroads.
} 
Likewise, Columns 3 and 4 show that the age of cars financed by The Bank declined by 0.436 and 0.599 years, respectively. Finally, we define a dummy variable that takes the value of one if the car is new and zero otherwise, and estimate the probability that The Bank will finance a new car after the reform. Columns 5 and 6 show that a new car is between 4.8 and 6.1 percentage points more likely to be financed by The Bank - representing an increase of between $22.9 \%$ and $29.1 \%$ relative to the mean.

Our results suggest that the reform enabled consumers to buy newer, more expensive cars. Further, the improvement in car characteristics was obtained through better contractual terms mostly by prolonging maturities. That is, the improvement in The Bank's ability to sell foreclosed cars led to better contracts that had an income effect on borrowers: their ability to borrow for longer terms and for lower spreads enabled them to buy newer, more expensive cars.

\section{F. The Effect of the Law on Delinquency and Default}

The results in Table 6 show that the credit reform led to the "democratization of credit" in that lower-income borrowers and borrowers with a higher risk of default were more likely to obtain car loans after the law was passed. But what about the performance of these loans? A growing body of empirical evidence suggests that credit expansion leads to subsequent waves of default and repossession (Keys et al. (2010), Mian and Sufi $(2009,2010)$ ). Did the reform lead to lax screening of borrowers?

We use three loan outcomes to capture the performance of loans: (i) late payment - a dummy variable that takes the value of one if the borrower was late on at least one payment even if it did not lead to a default, (ii) installment default - a dummy variable that takes the value of one if the borrower defaulted on at least one installment, and (iii) loan default - a dummy variable equal to one if the borrower was late for more than 90 days on at least one monthly installment.

We estimate the following equation using a linear probability model:

$$
\text { loanoutcome }_{i, t}=\alpha+\beta_{1} \times \text { law }_{i, t}+\mathbf{T}_{\mathbf{i}, \mathbf{t}} \lambda+\mathbf{b}_{\mathbf{i}} \psi+\mathbf{c}_{\mathbf{i}, \mathbf{t}} \theta+\mathbf{m}_{\mathbf{i}, \mathbf{t}} \xi+\mathbf{e}_{\mathbf{i}, \mathbf{t}} \gamma+\epsilon_{\mathbf{i}, \mathbf{t}}
$$

where the vectors $\mathbf{T}, \mathbf{b}, \mathbf{c}, \mathbf{m}$, and $\mathbf{e}$ are defined as before and the coefficient $\beta_{1}$ captures the effect of the law on borrowers' characteristics. Results are presented in Table 9.

The first column of the table reports the results from a linear probability regression in which the dependent variable is a late payment dummy variable. We find that after controlling for contract 
terms, personal and car characteristics, macro controls, and a time trend, the likelihood of a late payment increased after the reform. The effect of the law on the probability that the borrower will be late on at least one installment is fairly large - implying an increase of $18.8 \%$ relative to the mean. Similar results are obtained when we use - as our dependent variable - a dummy variable that takes the value of one if the borrower has defaulted on at least one installment (Column 2). As Table 9 shows, the coefficient on law, $\beta_{1}$, is significant at the $5 \%$ level and implies an increase in the likelihood of default of $21.3 \%$ relative to the sample mean. Likewise, a borrower is $18.8 \%$ more likely to be 90 days late on at least one installment - which, according to the Brazilian law, allows the bank to repossess the car - after the reform.

Taken together, the results in Table 9 demonstrate that auto loans signed after the implementation of the law performed worse than loans given in the 12 months before August 2004. It is important to note that once the law was passed, it affected all outstanding loans, including those that predated the law. We argue that the law enabled The Bank to expand credit to riskier borrowers because recovering collateral in the event of default became easier. Indeed, our previous results reported in Table 6 are consistent with the notion that the reform was associated with the provision of credit to riskier borrowers. The results in Table 6 that suggest that the law enhanced lending to riskier borrowers are based on observable characteristics such as income, risk, and job type. Interestingly, the results in Table 9 show that the likelihood that a borrower will be late on a loan and will eventually default is higher after the law was implemented even when we control for all observable borrower characteristics.

We now analyze the effect of the law on loan performance conditional on the borrower's risk and income. In Panel A of Table 10 we split the sample into low- and high-risk borrowers. None of the estimates are statistically significant, probably owing to the small sample size of the high-risk group (464 observations) and the relatively low frequency of late payments and default. Nevertheless, the coefficients are much larger in the high-risk compared to the low-risk group.

We conduct a similar analysis in Panel B, comparing the differential effect of the law on loan performance in the first and the fourth quartiles of income. Low-income individuals are more likely to be late on their payment (first two columns of Panel B) or default on their loan (last two columns). The economic significance of these effects is substantial, and it implies that the probability that a borrower will be late on a payment or default on a loan increases by $30.0 \%$ and $28.8 \%$, respectively. 
The results in Table 10 demonstrate again that even as the credit reform led to the "democratization" of access to credit, it also led to an expansion of credit to borrowers who were riskier and, indeed, increased the incidence of default and repossession.

\section{Conclusion}

We provide evidence from a 2004 credit reform in Brazil that simplified the selling of repossessed cars used as collateral for auto loans. Our evidence suggests that the legal change has led to larger loans with lower spreads, longer maturities, and higher leverage. It has also brought about a "democratization" of credit, enabling riskier, low-income borrowers to obtain loans and purchase newer, more expensive cars. Although the credit reform has improved access to credit by expanding credit to riskier borrowers, it has also led to increased incidences of default and repossession. In sum, this article provides evidence on the consequences of a credit reform, highlighting the crucial role that collateral plays in credit markets.

The evidence in this article shows that the ability to resell collateral enables banks to expand credit, mitigates financial shortfalls, and enhances the ability of borrowers to purchase newer, more expensive cars. Although we study the effect of a credit reform in Brazil using comprehensive data from one bank, our results propose a broader link, not confined only to Brazil or to the bank that provided us the data. An efficient legal system that enables creditors to repossess and resell

collateral facilitates credit provision, in particular to borrowers who would be otherwise left out of credit markets. 


\section{Appendix: Variable description and construction}

For reference, the following is a list of the variables used, their sources, and a brief description of how each is constructed.

1. Spread: The difference between the monthly interest rate paid by the borrower and the federal fund rate (in percentage points).

2. Maturity: Loan maturity (in months).

3. Down payment: The amount paid by the buyer that was not financed (in $\mathrm{R} \$$ ).

4. Loan size: The total amount financed by The Bank (in $\mathrm{R} \$$ ).

5. Law: A dummy variable that takes the value of one if the loan was initiated after the law was implemented, and zero otherwise.

6. Placebo law: A dummy variable that takes the value of one if the loan was initiated after August 2007, and zero otherwise.

7. Consumer leverage: The ratio of monthly loan installment to monthly borrower income.

8. Income: The borrower's (estimated) monthly income calculated by The Bank (in $\mathrm{R} \$$ ).

9. Client dummy: A dummy variable that takes the value of one if the borrower is a client of The Bank, and zero otherwise.

10. High risk dummy: A dummy variable that takes the value of one if the borrower is classified as a high risk, and zero otherwise.

11. Guarantor dummy: A dummy variable that takes the value of one if the loan has a guarantor, and zero otherwise.

12. Gender dummy: A dummy variable that takes the value of one if the borrower is a male, and zero otherwise.

13. Type of job: A five-category variable: employee, retired/pensioner, self-employed, entrepreneur, and other. 
14. Type of residence: A four-category variable: homeowner, lives with parents, renter, and other.

15. Marital status: A five-category variable: single, married, divorced, widower, and other.

16. New car: A dummy variable that takes the value of one if the car is new, and zero otherwise.

17. Car value: Car value (in $\mathrm{R} \$)$.

18. Model: Car model.

19. Car age: The difference (in years) between the date that the loan was signed and the date that the car was manufactured.

20. Dealer priority dummy: A dummy variable that takes the value of one if the consumer bought the car from a priority dealer, and zero otherwise.

21. Federal fund rate: The federal fund interest rate.

22. Inflation: The inflation rate over the last 12 months.

23. GDP growth: Quarterly GDP growth.

24. Late: A dummy variable that takes the value of one if the borrower was late on at least one installment, and zero otherwise.

25. Installment default: A dummy variable that takes the value of one if the borrower was late on at least two installments at the same time, and zero otherwise.

26. Default: A dummy variable that takes the value of one if the borrower was at least 90 days late, and zero otherwise. (This the criteria used by the Central bank). 


\section{References}

Aghion, P., and Patrick Bolton, 1992, An incomplete contracts approach to financial contracting, Review of Economic Studies 59, 1473-1494.

Amendolara, Cesar, 2006, Alienação fiduciária como instrumento de fomento a concessao de credito, in Ivo Waisberg and Marcos R. F. Fontes, eds.: Contratos Bancarios (Quartier Latin).

Atanasov, V., Bernard Black, Conrad Ciccotello, and Stanley Gyoshev, 2010, How does law affect finance? An examination of equity tunneling in Bulgaria, Journal of Financial Economics 96, 155-173.

Bae, Kee-Hong, and Vidhan K., Goyal, 2009, Creditor rights, enforcement, and bank loans, Journal of Finance 64, 823-860.

Beck, Thorsten, 2000, Impediments to the development and efficiency of financial intermediation in Brazil, Working paper, World Bank Policy Research.

Benmelech, Efraim, 2009, Asset salability and debt maturity: Evidence from 19th century American railroads, Review of Financial Studies 22, 1545-1583.

Benmelech, Efraim, and Nittai K. Bergman, 2008, Liquidation values and the credibility of financial contract renegotiation: Evidence from U.S. airlines, Quarterly Journal of Economics 123, 16351677.

Benmelech, Efraim, and Nittai K. Bergman, 2009, Collateral pricing, Journal of Financial Economics 91, 339-360.

Benmelech, Efraim, and Nittai K. Bergman, 2011, Vintage capital and creditor protection, Journal of Financial Economics 99, 308-332.

Benmelech, Efraim, Mark J. Garmaise, and Tobias J. Moskowitz, 2005, Do liquidation values affect financial contracts? Evidence from commercial loan contracts and zoning regulation, Quarterly Journal of Economics 120, 1121-1154.

Berger, A., and Gregory Udell, 1990, Collateral, loan quality and bank risk, Journal of Monetary Economics 25, 21-42.

Bertrand, Marianne, Antoinette Schoar, and David Thesmar, 2007, Banking deregulation and industry structure: Evidence from the French banking reforms of 1985, Journal of Finance 62 597-628.

van Binsbergen, J., John Graham, and Jie Yang, 2010, The cost of debt, Journal of Finance 65, 2089-2136.

Bolton, P., and David S. Scharfstein, 1996, Optimal debt structure and the number of creditors, Journal of Political Economy 104, 1-25.

Boot, A., and Anjan Thakor, 1991, Off-balance sheet liabilities, deposit insurance and capital regulation, Journal of Banking \& Finance 15, 825-846.

Coelho, Christiano A., Buno Funchal, and Joao M. P. de Mello, forthcoming, The Brazilian payroll lending experiment, Review of Economics and Statistics.

Costa, Ana C. A., and Joao M. P. de Mello, 2006, Judicial risk and credit market performance: Micro evidence from Brazilian payroll loans, Working paper, NBER.

Demirguc-Kunt, Asli, Luc Laeven, and Ross Levine, 2004, Regulations, market structure, institutions, and the cost of financial intermediation, Journal of Money, Credit, and Banking 36, 593-622. 
Djankov, S., Oliver Hart, C. McLiesh, and Andrei Shleifer, 2008, Debt enforcement around the world, Journal of Political Economy 116, 1105-1149.

Djankov, S., C. McLiesh, and Andrei Shleifer, 2007, Private credit in 129 countries, Journal of Financial Economics 84, 299-329.

Einav, Liran, Mark Jenkins, and Jonathan Levin, The impact of information technology on consumer credit markets (Stanford University, mimeo).

Eisfeldt, A., and Adriano Rampini, 2009, Leasing, ability to repossess, and debt capacity, Review of Financial Studies 22, 1621-1257.

Hart, O., and John Moore, 1994, A theory of debt based on the inalienability of human capital, Quarterly Journal of Economics 109, 841-879.

Hart, O., and John Moore, 1998, Default and renegotiation: A dynamic model of debt, Quarterly Journal of Economics 113, 1-41.

Haselmann, R., Katharina Pistor, and Vikrant Vig, 2010, How law affects lending, Review of Financial Studies 23, 549-580.

Jappelli, Tullio, Marco Pagano, and Magda Bianco, 2005, Courts and banks: Effects of judicial enforcement on credit markets, Journal of Money, Credit, and Banking 37, 223-244.

Jimenez, G., Vicente Salas, and Jesus Saurina, 2006, Determinants of collateral, Journal of Financial Economics 81, 255-281.

John, K., Anthony Lynch, and Manju Puri, 2003, Credit ratings, collateral, and loan characteristics: Implications for yield, Journal of Business 76, 371-409

Johnson, H., and Rene Stulz, 1985, An analysis of secured debt, Journal of Financial Economics $14,501-521$.

Kaplan, S., Frederic Martel, and Per Stromberg, 2007, How do legal differences and experience affect financial contracts?, Journal of financial intermediation 16, 273-311.

Keys, Benjamin J., Tanmoy Mukherjee, Amit Seru, and Vikrant Vig, 2010, Did securitization lead to lax screening? Evidence from subprime loans, Quarterly Journal of Economics 125, 307-362.

La Porta, R., F. Lopez-de-Silanes, Andrei Shleifer, and Robert Vishny, 1997, Legal determinants of external finance, Journal of Finance 52, 2803-2834.

La Porta, R., F. Lopez-de-Silanes, Andrei Shleifer, and Robert Vishny, 1998, Law and finance, Journal of Political Economy 106, 1113-1155.

Laeven, Luc, and Giovanni Majnoni, 2005, Does judicial Efficiency lower the cost of credit?, Journal of Banking and Finance 29, 1791-1812.

Lerner, Josh, and Antoinette Schoar, 2005, Does legal enforcement affect financial transactions? The contractual channel in private equity, Quarterly Journal of Economics 120, 223-246.

Liberty, Jose, and Atif Mian, 2010, Collateral spread and financial development, Journal of Finance $65,147-177$.

Mian, Atif, and Amir Sufi, 2009, The consequences of mortgage credit expansion: Evidence from the U.S. mortgage default crisis, Quarterly Journal of Economics 124, 1449-1496.

Mian, Atif, and Amir Sufi, 2010, The great recession: Lessons from microeconomic data, American Economic Review: Papers and Proceedings 100, 1-10. 
Petersen, Mitchell A., and Raghuram G. Rajan, 2007, The benefits of lending relationships: Evidence from small business data, Journal of Finance 62, 2803-2834.

Qian, Jun, and Philip E. Strahan, 2007, How laws and institutions shape financial contracts: The case of bank loans, Journal of Finance 62, 2803-2834.

Rampini, A., and S. Viswanathan, 2010, Collateral, risk management, and the distribution of debt capacity, Journal of Finance 65, 2293-2322.

Shleifer, Andrei, and Robert W. Vishny, 1992, Liquidation values and debt capacity: A market equilibrium approach, Journal of Finance 47, 143-166.

Vig, V., 2011, Access to collateral and corporate debt structure: Evidence from a natural experiment, EFA 2008 Athens Meetings Paper. 
Table 1:

Summary Statistics

This table provides descriptive statistics for the variables used in the empirical analysis.

\begin{tabular}{|c|c|c|c|c|c|}
\hline \multicolumn{6}{|c|}{ Panel A: Contract characteristics } \\
\hline & \multicolumn{3}{|c|}{5 th } & \multirow{2}{*}{$\begin{array}{c}95 \text { th } \\
\text { Percentile }\end{array}$} & \multirow{2}{*}{$\begin{array}{l}\text { Standard } \\
\text { Deviation }\end{array}$} \\
\hline & Mean & Percentile & Median & & \\
\hline Spread & 1.10 & 0.20 & 1.08 & 2.20 & 0.66 \\
\hline Maturity & 36.1 & 18.0 & 36.0 & 48.0 & 10.9 \\
\hline Down payment & 6,903 & 1,487 & 4,461 & 16,249 & 35,269 \\
\hline Total financed $(\mathrm{R} \$)$ & 9,760 & 3,287 & 8,545 & 20,119 & 5,819 \\
\hline Car value $(\mathrm{R} \$)$ & 16,663 & 6,716 & 14,127 & 30,590 & 35,813 \\
\hline Consumer leverage & 24.9 & 8.0 & 23.9 & 46.1 & 21.4 \\
\hline
\end{tabular}

Panel B: Borrower characteristics

\begin{tabular}{|c|c|c|c|c|c|}
\hline & \multicolumn{3}{|c|}{5 th } & \multirow{2}{*}{$\begin{array}{c}95 \text { th } \\
\text { Percentile }\end{array}$} & \multirow{2}{*}{$\begin{array}{l}\text { Standard } \\
\text { Deviation }\end{array}$} \\
\hline & Mean & Percentile & Median & & \\
\hline Income $(\mathrm{R} \$)$ & 3,065 & 803 & 1,706 & 6,181 & 23,986 \\
\hline Client of the bank & 0.24 & 0.0 & 0.0 & 1.0 & 0.43 \\
\hline Guarantor & 0.08 & 0.0 & 0.0 & 1.0 & 0.26 \\
\hline High risk & 0.03 & 0.0 & 0.0 & 0.0 & 0.16 \\
\hline Medium risk & 0.25 & 0.0 & 0.0 & 1.0 & 0.43 \\
\hline Low risk & 0.73 & 0.0 & 1.0 & 1.0 & 0.45 \\
\hline Male & 0.66 & 0.0 & 1.0 & 1.0 & 0.47 \\
\hline Single & 0.40 & 0.0 & 0.0 & 1.0 & 0.49 \\
\hline Married & 0.45 & 0.0 & 0.0 & 1.0 & 0.50 \\
\hline Homeowner & 0.83 & 0.0 & 1.0 & 1.0 & 0.38 \\
\hline Lives with parents & 0.13 & 0.0 & 0.0 & 1.0 & 0.33 \\
\hline Employee & 0.59 & 0.0 & 1.0 & 1.0 & 0.49 \\
\hline Retired/pensioner & 0.12 & 0.0 & 0.0 & 1.0 & 0.32 \\
\hline Self-employed/entrepreneur & 0.26 & 0.0 & 0.0 & 1.0 & 0.44 \\
\hline \multicolumn{6}{|c|}{ Panel C: Car characteristics } \\
\hline & & 5 th & & 95 th & Standard \\
\hline & Mean & Percentile & Median & Percentile & Deviation \\
\hline New & 0.21 & 0.0 & 0.0 & 1.0 & 0.41 \\
\hline Age & 5.32 & 0.0 & 5.0 & 13.0 & 4.28 \\
\hline Dealer priority & 0.88 & 0.0 & 1.0 & 1.0 & 0.33 \\
\hline
\end{tabular}


Table 1 - cont'd

Summary Statistics

\begin{tabular}{|c|c|c|c|c|c|}
\hline \multicolumn{6}{|c|}{ Panel D: Loan outcome characteristics } \\
\hline & \multicolumn{3}{|c|}{5 th } & 95 th & Standard \\
\hline & Mean & Percentile & Median & Percentile & Deviation \\
\hline Late & 0.08 & 0.0 & 0.0 & 1.0 & 0.27 \\
\hline Installment default & 0.09 & 0.0 & 0.0 & 1.0 & 0.29 \\
\hline Default & 0.08 & 0.0 & 0.0 & 1.0 & 0.26 \\
\hline \multicolumn{6}{|c|}{ Panel E: Macro Controls } \\
\hline & \multicolumn{3}{|c|}{5 th } & 95 th & Standard \\
\hline & Mean & Percentile & Median & Percentile & Deviation \\
\hline Federal fund rate (monthly) & $1.42 \%$ & $1.24 \%$ & $1.37 \%$ & $1.67 \%$ & $0.15 \%$ \\
\hline Inflation rate (12 months) & $8.92 \%$ & $5.89 \%$ & $7.60 \%$ & $15.14 \%$ & $2.90 \%$ \\
\hline GDP growth (quarterly seasonally adjusted) & $1.15 \%$ & $-0.22 \%$ & $1.26 \%$ & $2.36 \%$ & $0.84 \%$ \\
\hline
\end{tabular}


Table 2:

Summary Statistics: Before and after the law

This table reports descriptive statistics for the main variables used in the empirical analysis before and after enactment of the law.

Panel A: Contract characteristics

\begin{tabular}{|c|c|c|c|c|c|c|c|}
\hline & \multicolumn{3}{|c|}{ before } & \multicolumn{3}{|c|}{ after } & \multirow[b]{2}{*}{$\begin{array}{c}\text { difference } \\
\text { p-value }\end{array}$} \\
\hline & Mean & Median & $\begin{array}{l}\text { Standard } \\
\text { Deviation }\end{array}$ & Mean & Median & $\begin{array}{l}\text { Standard } \\
\text { Deviation }\end{array}$ & \\
\hline Spread & 1.18 & 1.15 & 0.57 & 1.02 & 0.98 & 0.74 & 0.00 \\
\hline Maturity & 34.6 & 36.0 & 10.1 & 37.7 & 36.0 & 11.2 & 0.00 \\
\hline Down payment & 7,400 & 4,435 & 47,975 & 6,333 & 4,512 & 5,328 & 0.05 \\
\hline Total financed & 9,115 & 7,983 & 5,407 & 10,501 & 9,127 & 6,176 & 0.00 \\
\hline Car value & 16,514 & 13,381 & 15,530 & 16,834 & 15,284 & 8,392 & 0.56 \\
\hline Consumer leverage & 24.5 & 23.0 & 18.4 & 26.5 & 24.2 & 24.4 & 0.00 \\
\hline \multicolumn{8}{|c|}{ Panel B: Borrower characteristics } \\
\hline & \multicolumn{3}{|c|}{ before } & \multicolumn{3}{|c|}{ after } & \\
\hline & Mean & Median & $\begin{array}{l}\text { Standard } \\
\text { Deviation }\end{array}$ & Mean & Median & $\begin{array}{l}\text { Standard } \\
\text { Deviation }\end{array}$ & $\begin{array}{c}\text { difference } \\
\text { p-value }\end{array}$ \\
\hline Income & 3,105 & 1,673 & 12,997 & 3,021 & 1,760 & 32,285 & 0.82 \\
\hline Client of the bank & 0.24 & 0.0 & 0.49 & 0.24 & 0.0 & 0.43 & 0.79 \\
\hline Guarantor & 0.08 & 0.0 & 0.27 & 0.07 & 0.0 & 0.25 & 0.00 \\
\hline High risk & 0.02 & 0.0 & 0.13 & 0.04 & 0.0 & 0.19 & 0.00 \\
\hline Medium risk & 0.25 & 0.0 & 0.43 & 0.24 & 0.0 & 0.43 & 0.26 \\
\hline Low risk & 0.73 & 1.0 & 0.44 & 0.72 & 1.0 & 0.44 & 0.07 \\
\hline Male & 0.66 & 1.0 & 0.47 & 0.66 & 1.0 & 0.48 & 0.54 \\
\hline Single & 0.39 & 0.0 & 0.49 & 0.40 & 0.0 & 0.49 & 0.42 \\
\hline Married & 0.45 & 0.0 & 0.50 & 0.44 & 0.0 & 0.50 & 0.46 \\
\hline Homeowner & 0.83 & 1.0 & 0.38 & 0.83 & 1.0 & 0.38 & 0.74 \\
\hline Lives with parents & 0.13 & 0.0 & 0.34 & 0.13 & 0.0 & 0.33 & 0.21 \\
\hline Employee & 0.61 & 1.0 & 0.49 & 0.58 & 1.0 & 0.49 & 0.00 \\
\hline Retired/pensioner & 0.12 & 0.0 & 0.32 & 0.11 & 0.0 & 0.31 & 0.02 \\
\hline Self-employed/entrepreneur & 0.24 & 0.0 & 0.43 & 0.29 & 0.0 & 0.45 & 0.00 \\
\hline
\end{tabular}


Table 3:

\section{The Effect of the Law on Loan Contracts}

Panel A of this table reports results from regressing loan characteristics on law, and Panel B reports results from regressing loan characteristics on a placebo law. We use four measures of loan characteristics: spread, loan maturity, loan size, and consumer leverage. All regressions include an intercept. The regressions control for contract terms (spread, maturity, and down payment), borrower characteristics (income, borrower type of risk, gender, presence of a guarantor, type of job, type of residence, marital status, and whether the borrower is a client of The Bank), car characteristics (a dummy for new car, car age, and dealer priority), macro variables (inflation, federal fund rate, quarterly GDP growth, and time trend), car model fixed-effects, and state fixed-effects. Standard errors are calculated by clustering at both the state and month levels. Variables definitions are provided in the Appendix. ***, **, and $*$ denote statistical significance at the $1 \%, 5 \%$, and $10 \%$ levels, respectively.

\begin{tabular}{|c|c|c|c|c|}
\hline \multicolumn{5}{|c|}{ Panel A: Treatment Regressions (August 2003 - July 2005) } \\
\hline $\begin{array}{l}\text { Dependent } \\
\text { Variable= }\end{array}$ & spread & maturity & $\log ($ loan size $)$ & leverage \\
\hline Law & $\begin{array}{c}-0.106^{* * *} \\
(0.028)\end{array}$ & $\begin{array}{c}2.073^{* * *} \\
(0.290)\end{array}$ & $\begin{array}{c}0.019^{* * *} \\
(0.006)\end{array}$ & $\begin{array}{c}1.841^{* * *} \\
(0.401)\end{array}$ \\
\hline Contract terms & Yes & Yes & Yes & Yes \\
\hline Personal characteristics & Yes & Yes & Yes & Yes \\
\hline Car characteristics & Yes & Yes & Yes & Yes \\
\hline Car model fixed-effects & Yes & Yes & Yes & Yes \\
\hline Macro controls & Yes & Yes & Yes & Yes \\
\hline Time trend & Yes & Yes & Yes & Yes \\
\hline State fixed-effects & Yes & Yes & Yes & Yes \\
\hline Observations & 17,349 & 17,349 & 17,349 & 17,349 \\
\hline Adjusted $R^{2}$ & 0.587 & 0.269 & 0.770 & 0.335 \\
\hline \multicolumn{5}{|c|}{ Panel B: Placebo Regressions (August 2006 - July 2008) } \\
\hline $\begin{array}{l}\text { Dependent } \\
\text { Variable= }\end{array}$ & spread & maturity & $\log ($ total size $)$ & leverage \\
\hline Placebo law & $\begin{array}{c}0.057^{* * *} \\
(0.021)\end{array}$ & $\begin{array}{l}-0.260 \\
(0.477)\end{array}$ & $\begin{array}{l}-0.004 \\
(0.005)\end{array}$ & $\begin{array}{l}-0.399 \\
(0.514)\end{array}$ \\
\hline Contract terms & Yes & Yes & Yes & Yes \\
\hline Personal characteristics & Yes & Yes & Yes & Yes \\
\hline Car characteristics & Yes & Yes & Yes & Yes \\
\hline Car model fixed-effects & Yes & Yes & Yes & Yes \\
\hline Macro controls & Yes & Yes & Yes & Yes \\
\hline Time trend & Yes & Yes & Yes & Yes \\
\hline State fixed-effects & Yes & Yes & Yes & Yes \\
\hline Observations & 30,375 & 30,375 & 30,375 & 30,375 \\
\hline Adjusted $R^{2}$ & 0.599 & 0.402 & 0.801 & 0.300 \\
\hline
\end{tabular}




\section{Table 4: \\ Speed of Repossession and Loan Maturity}

Panel A of this table reports results from regressing measures of loan maturity on law, and Panel B reports results from regressing measures loan maturity on placebo law. We use three measures of loan maturity: a dummy variable that takes the value of one if maturity is 2 years or longer, 3 years or longer, and 4 years or longer. All regressions include an intercept. The regressions control for contract terms (spread, and down payment), borrower characteristics (income, borrower type of risk, gender, presence of a guarantor, type of job, type of residence, marital status, and whether the borrower is a client of The Bank), car characteristics (a dummy for new car, car age, and dealer priority), macro variables (inflation, federal fund rate, quarterly GDP growth, and time trend), car model fixed-effects, and state fixed-effects. Standard errors are calculated by clustering at both the state and month levels. Variables definitions are provided in the Appendix. ***, **, and $*$ denote statistical significance at the $1 \%, 5 \%$, and $10 \%$ levels, respectively.

\begin{tabular}{|c|c|c|c|}
\hline \multicolumn{4}{|c|}{ Panel A: Treatment Regressions (August 2003 - July 2005) } \\
\hline $\begin{array}{l}\text { Dependent } \\
\text { Variable }=\end{array}$ & $\begin{array}{c}\text { maturity } \\
\text { (2 years or longer) }\end{array}$ & $\begin{array}{c}\text { maturity } \\
\text { (3 years or longer) }\end{array}$ & $\begin{array}{c}\text { maturity } \\
\text { (4 years or longer) }\end{array}$ \\
\hline Law & $\begin{array}{c}0.031^{* * *} \\
(0.007)\end{array}$ & $\begin{array}{c}0.063^{* * *} \\
(0.011)\end{array}$ & $\begin{array}{c}0.070^{* * *} \\
(0.013)\end{array}$ \\
\hline Contract terms & Yes & Yes & Yes \\
\hline Personal characteristics & Yes & Yes & Yes \\
\hline Car characteristics & Yes & Yes & Yes \\
\hline Car model fixed-effects & Yes & Yes & Yes \\
\hline Macro controls & Yes & Yes & Yes \\
\hline Time trend & Yes & Yes & Yes \\
\hline State fixed-effects & Yes & Yes & Yes \\
\hline Observations & 17,349 & 17,349 & 17,349 \\
\hline Adjusted $R^{2}$ & 0.096 & 0.189 & 0.271 \\
\hline \multicolumn{4}{|c|}{ Panel B: Placebo Regressions (August 2006 - July 2008) } \\
\hline $\begin{array}{l}\text { Dependent } \\
\text { Variable }=\end{array}$ & $\begin{array}{c}\text { maturity } \\
\text { (2 years or longer })\end{array}$ & $\begin{array}{c}\text { maturity } \\
\text { (3 years or longer) }\end{array}$ & $\begin{array}{c}\text { maturity } \\
\text { (4 years or longer) }\end{array}$ \\
\hline Placebo law & $\begin{array}{l}-0.001 \\
(0.005)\end{array}$ & $\begin{array}{l}-0.006 \\
(0.008)\end{array}$ & $\begin{array}{l}-0.010 \\
(0.015)\end{array}$ \\
\hline Contract terms & Yes & Yes & Yes \\
\hline Personal characteristics & Yes & Yes & Yes \\
\hline Car characteristics & Yes & Yes & Yes \\
\hline Car model fixed-effects & Yes & Yes & Yes \\
\hline Macro controls & Yes & Yes & Yes \\
\hline Time trend & Yes & Yes & Yes \\
\hline State fixed-effects & Yes & Yes & Yes \\
\hline Observations & 30,375 & 30,375 & 30,375 \\
\hline Adjusted $R^{2}$ & 0.064 & 0.172 & 0.346 \\
\hline
\end{tabular}


Table 5:

\section{The Effect of the Law on Loan Contracts Stratified by Car Age}

This table reports results from regressing loan characteristics on law. Panel A stratifies the sample into new car (odd columns) and used car (even columns). Panel B stratifies the sample into used car up to 5 years (odd columns) and more than 5 years (even columns). We use four measures of loan characteristics: spread, loan maturity, loan size, and consumer leverage. All regressions include an intercept. The regressions control for contract terms (spread, maturity, and down payment), borrower characteristics (income, borrower type of risk, gender, presence of a guarantor, type of job, type of residence, marital status, and whether the borrower is a client of The Bank), car characteristics (a dummy for new car, car age, and dealer priority), macro variables (inflation, federal fund rate, quarterly GDP growth, and time trend), car model fixed-effects, and state fixed-effects. Standard errors are calculated by clustering at both the state and month levels. Variables definitions are provided in the Appendix. ***, **, and $*$ denote statistical significance at the $1 \%, 5 \%$, and $10 \%$ levels, respectively.

\section{Panel A: New versus Used}

\begin{tabular}{|c|c|c|c|c|c|c|c|c|}
\hline \multirow[t]{2}{*}{ Dependent Variable $=$} & \multicolumn{2}{|c|}{$\begin{array}{l}\text { spread } \\
\text { car }\end{array}$} & \multicolumn{2}{|c|}{$\begin{array}{l}\text { maturity } \\
\text { car }\end{array}$} & \multicolumn{2}{|c|}{$\begin{array}{c}\log (\operatorname{loan} \text { size }) \\
c a r\end{array}$} & \multicolumn{2}{|c|}{$\begin{array}{l}\text { leverage } \\
\quad \text { car }\end{array}$} \\
\hline & new & used & new & used & new & used & new & used \\
\hline Law & $\begin{array}{c}-0.344^{* * *} \\
(0.038)\end{array}$ & $\begin{array}{l}-0.027 \\
(0.032)\end{array}$ & $\begin{array}{c}5.882^{* * *} \\
(0.826)\end{array}$ & $\begin{array}{c}1.594^{* * *} \\
(0.385)\end{array}$ & $\begin{array}{c}0.120^{* * *} \\
(0.016)\end{array}$ & $\begin{array}{c}0.004 \\
(0.010)\end{array}$ & $\begin{array}{c}5.229^{* * *} \\
(1.395)\end{array}$ & $\begin{array}{c}1.114^{* * *} \\
(0.383)\end{array}$ \\
\hline Contract terms & Yes & Yes & Yes & Yes & Yes & Yes & Yes & Yes \\
\hline Personal characteristics & Yes & Yes & Yes & Yes & Yes & Yes & Yes & Yes \\
\hline Car characteristics & Yes & Yes & Yes & Yes & Yes & Yes & Yes & Yes \\
\hline Car model fixed-effects & Yes & Yes & Yes & Yes & Yes & Yes & Yes & Yes \\
\hline Macro controls & Yes & Yes & Yes & Yes & Yes & Yes & Yes & Yes \\
\hline Time trend & Yes & Yes & Yes & Yes & Yes & Yes & Yes & Yes \\
\hline State fixed-effects & Yes & Yes & Yes & Yes & Yes & Yes & Yes & Yes \\
\hline Observations & 3,702 & 13,645 & 3,702 & 13,645 & 3,702 & 13,645 & 3,702 & 13,645 \\
\hline Adjusted $R^{2}$ & 0.309 & 0.451 & 0.367 & 0.330 & 0.623 & 0.690 & 0.414 & 0.315 \\
\hline
\end{tabular}

\section{Panel B: Used Cars only}

\begin{tabular}{|c|c|c|c|c|c|c|c|c|}
\hline \multirow[t]{2}{*}{ Dependent Variable= } & \multicolumn{2}{|c|}{$\begin{array}{l}\text { spread } \\
\text { car }\end{array}$} & \multicolumn{2}{|c|}{$\begin{array}{l}\text { maturity } \\
\text { car }\end{array}$} & \multicolumn{2}{|c|}{$\begin{array}{c}\log (\operatorname{loan} \text { size }) \\
c a r\end{array}$} & \multicolumn{2}{|c|}{$\begin{array}{l}\text { leverage } \\
\quad \text { car }\end{array}$} \\
\hline & $\begin{array}{l}\text { up to } \\
5 \text { years }\end{array}$ & $\begin{array}{l}\text { more than } \\
5 \text { years }\end{array}$ & $\begin{array}{l}\text { up to } \\
5 \text { years }\end{array}$ & $\begin{array}{l}\text { more than } \\
5 \text { years }\end{array}$ & $\begin{array}{c}\text { up to } \\
5 \text { years }\end{array}$ & $\begin{array}{l}\text { more than } \\
5 \text { years }\end{array}$ & $\begin{array}{l}\text { up to } \\
5 \text { years }\end{array}$ & $\begin{array}{c}\text { more than } \\
5 \text { years }\end{array}$ \\
\hline Law & $\begin{array}{l}-0.071^{*} \\
(0.037)\end{array}$ & $\begin{array}{c}0.003 \\
(0.030)\end{array}$ & $\begin{array}{c}2.157^{* * *} \\
(0.654)\end{array}$ & $\begin{array}{c}1.178^{* * *} \\
(0.358)\end{array}$ & $\begin{array}{c}0.0274^{*} \\
(0.016)\end{array}$ & $\begin{array}{l}-0.008 \\
(0.015)\end{array}$ & $\begin{array}{l}1.472^{*} \\
(0.762)\end{array}$ & $\begin{array}{c}0.974^{* *} \\
(0.493)\end{array}$ \\
\hline Contract terms & Yes & Yes & Yes & Yes & Yes & Yes & Yes & Yes \\
\hline Personal characteristics & Yes & Yes & Yes & Yes & Yes & Yes & Yes & Yes \\
\hline Car characteristics & Yes & Yes & Yes & Yes & Yes & Yes & Yes & Yes \\
\hline Car model fixed-effects & Yes & Yes & Yes & Yes & Yes & Yes & Yes & Yes \\
\hline Macro controls & Yes & Yes & Yes & Yes & Yes & Yes & Yes & Yes \\
\hline Time trend & Yes & Yes & Yes & Yes & Yes & Yes & Yes & Yes \\
\hline State fixed-effects & Yes & Yes & Yes & Yes & Yes & Yes & Yes & Yes \\
\hline Observations & 5,299 & 8,346 & 5,299 & 8,346 & 5,299 & 8,346 & 5,299 & 8,346 \\
\hline Adjusted $R^{2}$ & 0.272 & 0.434 & 0.308 & 0.354 & 0.607 & 0.689 & 0.307 & 0.387 \\
\hline
\end{tabular}




\section{The Effect of the Law on Borrower Characteristics}

This table reports results from regressing borrower characteristics on law. We use three borrower characteristics as dependent variables: income, borrower risk, and whether the borrower is selfemployed/entrepreneur. All regressions include an intercept. The regressions control for contract terms (spread, maturity, and down payment), borrower characteristics (income, borrower type of risk, gender, presence of a guarantor, type of job, type of residence, marital status, and whether the borrower is a client of The Bank), car characteristics (a dummy for new car, car age, and dealer priority), macro variables (inflation, federal fund rate, quarterly GDP growth, and time trend), car model fixedeffects, and state fixed-effects. Standard errors are calculated by clustering at both the state and month levels. Variables definitions are provided in the Appendix. $* * *, * *$, and $*$ denote statistical significance at the $1 \%, 5 \%$, and $10 \%$ levels, respectively.

\begin{tabular}{lccc}
\hline \hline $\begin{array}{l}\text { Dependent } \\
\text { Variable }=\end{array}$ & log(income) & high risk & $\begin{array}{c}\text { self-employed/ } \\
\text { entrepreneur }\end{array}$ \\
\hline Law & $-0.032^{* *}$ & $0.014^{* * *}$ & $0.051^{* * *}$ \\
& $(0.015)$ & $(0.004)$ & $(0.013)$ \\
Contract terms & Yes & Yes & Yes \\
Personal characteristics & Yes & Yes & Yes \\
Car characteristics & Yes & Yes & Yes \\
Car model fixed-effects & Yes & Yes & Yes \\
Macro controls & Yes & Yes & Yes \\
Time trend & Yes & Yes & Yes \\
State fixed-effects & Yes & Yes & Yes \\
& & & \\
Observations & 17,349 & 17,349 & 17,349 \\
Adjusted $R^{2}$ & 0.357 & 0.058 & 0.071 \\
\hline \hline
\end{tabular}




\section{Table 7: \\ The Effect of the Law on Loan Contracts Stratified by Risk and Income}

This table reports results from regressing loan characteristics on law. Panel A stratifies the sample into low risk (odd columns) and high risk (even columns). Panel B stratifies the sample into low income (odd columns) and high income (even columns). We use four measures of loan characteristics: spread, loan maturity, loan size, and consumer leverage. All regressions include an intercept. The regressions control for contract terms (spread, maturity, and down payment), borrower characteristics (income, borrower type of risk, gender, presence of a guarantor, type of job, type of residence, marital status, and whether the borrower is a client of The Bank), car characteristics (a dummy for new car, car age, and dealer priority), macro variables (inflation, federal fund rate, quarterly GDP growth, and time trend), car model fixed-effects, and state fixed-effects. Standard errors are calculated by clustering at both the state and month levels. Variables definitions are provided in the Appendix. ***,**, and $*$ denote statistical significance at the $1 \%, 5 \%$, and $10 \%$ levels, respectively.

\section{Panel A: Stratified by risk}

\begin{tabular}{|c|c|c|c|c|c|c|c|c|}
\hline \multirow[t]{2}{*}{ Dependent Variable $=$} & \multicolumn{2}{|c|}{$\begin{array}{l}\text { spread } \\
\text { risk }\end{array}$} & \multicolumn{2}{|c|}{$\begin{array}{c}\text { maturity } \\
\text { risk }\end{array}$} & \multicolumn{2}{|c|}{$\begin{array}{c}\log (\operatorname{loan} \text { size }) \\
\text { risk }\end{array}$} & \multicolumn{2}{|c|}{$\begin{array}{l}\text { leverage } \\
\text { risk }\end{array}$} \\
\hline & low & high & low & high & low & high & low & high \\
\hline Law & $\begin{array}{c}-0.117^{* * *} \\
(0.031)\end{array}$ & $\begin{array}{c}0.027 \\
(0.075)\end{array}$ & $\begin{array}{c}1.991^{* * *} \\
(0.354)\end{array}$ & $\begin{array}{c}0.513 \\
(1.572)\end{array}$ & $\begin{array}{c}0.028^{* * *} \\
(0.007)\end{array}$ & $\begin{array}{l}-0.034 \\
(0.036)\end{array}$ & $\begin{array}{c}1.950^{* * *} \\
(0.506)\end{array}$ & $\begin{array}{c}0.945 \\
(2.805)\end{array}$ \\
\hline Contract terms & Yes & Yes & Yes & Yes & Yes & Yes & Yes & Yes \\
\hline Personal characteristics & Yes & Yes & Yes & Yes & Yes & Yes & Yes & Yes \\
\hline Car characteristics & Yes & Yes & Yes & Yes & Yes & Yes & Yes & Yes \\
\hline Car model fixed-effects & Yes & Yes & Yes & Yes & Yes & Yes & Yes & Yes \\
\hline Macro controls & Yes & Yes & Yes & Yes & Yes & Yes & Yes & Yes \\
\hline Time trend & Yes & Yes & Yes & Yes & Yes & Yes & Yes & Yes \\
\hline State fixed-effects & Yes & Yes & Yes & Yes & Yes & Yes & Yes & Yes \\
\hline Observations & 12,623 & 464 & 12,623 & 464 & 12,623 & 464 & 12,623 & 464 \\
\hline Adjusted $R^{2}$ & 0.583 & 0.662 & 0.264 & 0.537 & 0.761 & 0.909 & 0.364 & 0.440 \\
\hline
\end{tabular}

Panel B: Stratified by income

\begin{tabular}{|c|c|c|c|c|c|c|c|c|}
\hline \multirow[t]{2}{*}{ Dependent Variable $=$} & \multicolumn{2}{|c|}{$\begin{array}{l}\text { spread } \\
\text { income }\end{array}$} & \multicolumn{2}{|c|}{$\begin{array}{l}\text { maturity } \\
\text { income }\end{array}$} & \multicolumn{2}{|c|}{$\begin{array}{c}\log (\operatorname{loan} \text { size }) \\
\text { income }\end{array}$} & \multicolumn{2}{|c|}{$\begin{array}{c}\text { leverage } \\
\text { income }\end{array}$} \\
\hline & low & high & low & high & low & high & low & high \\
\hline Law & $\begin{array}{c}0.035 \\
(0.041)\end{array}$ & $\begin{array}{c}-0.173^{* * *} \\
(0.037)\end{array}$ & $\begin{array}{c}2.227^{* * *} \\
(0.424)\end{array}$ & $\begin{array}{c}2.716^{* * *} \\
(0.593)\end{array}$ & $\begin{array}{c}0.003 \\
(0.012)\end{array}$ & $\begin{array}{c}0.022 \\
(0.014)\end{array}$ & $\begin{array}{c}0.693 \\
(0.992)\end{array}$ & $\begin{array}{c}2.144^{* * *} \\
(0.789)\end{array}$ \\
\hline Contract terms & Yes & Yes & Yes & Yes & Yes & Yes & Yes & Yes \\
\hline Personal characteristics & Yes & Yes & Yes & Yes & Yes & Yes & Yes & Yes \\
\hline Car characteristics & Yes & Yes & Yes & Yes & Yes & Yes & Yes & Yes \\
\hline Car model fixed-effects & Yes & Yes & Yes & Yes & Yes & Yes & Yes & Yes \\
\hline Macro controls & Yes & Yes & Yes & Yes & Yes & Yes & Yes & Yes \\
\hline Time trend & Yes & Yes & Yes & Yes & Yes & Yes & Yes & Yes \\
\hline State fixed-effects & Yes & Yes & Yes & Yes & Yes & Yes & Yes & Yes \\
\hline Observations & 4,365 & 4,301 & 4,365 & 4,301 & 4,365 & 4,301 & 4,365 & 4,301 \\
\hline Adjusted $R^{2}$ & 0.652 & 0.456 & 0.374 & 0.255 & 0.771 & 0.666 & 0.500 & 0.202 \\
\hline
\end{tabular}




\section{Table 8:
The Effect of the Law on Car Characteristics}

This table reports results from regressing car characteristics on law. We use log(car value), car age, and a dummy variable indicating whether the car is new as dependent variables. All regressions include an intercept. The regressions on odd columns control for borrower characteristics (income, borrower type of risk, gender, presence of a guarantor, type of job, type of residence, marital status, and whether the borrower is a client of The Bank), car characteristics (dealer priority), macro variables (inflation, federal fund rate, quarterly GDP growth, and time trend), car model fixed-effects, and state fixed-effects. The regressions in even columns do not control for car model fixed-effects. Standard errors are calculated by clustering at both the state and month levels. Variables definitions are provided in the Appendix. $* * *, * *$, and $*$ denote statistical significance at the $1 \%, 5 \%$, and $10 \%$ levels, respectively.

\begin{tabular}{|c|c|c|c|c|c|c|}
\hline $\begin{array}{l}\text { Dependent } \\
\text { Variable= }\end{array}$ & $\log ($ car value $)$ & $\log ($ car value $)$ & car age & car age & new car & new car \\
\hline Law & $\begin{array}{c}0.020^{* * *} \\
(0.006)\end{array}$ & $\begin{array}{c}0.077 * * * \\
(0.014)\end{array}$ & $\begin{array}{c}-0.436^{* * *} \\
(0.081)\end{array}$ & $\begin{array}{c}-0.599 * * * \\
(0.120)\end{array}$ & $\begin{array}{c}0.048^{* * *} \\
(0.012)\end{array}$ & $\begin{array}{c}0.061^{* * *} \\
(0.013)\end{array}$ \\
\hline Personal characteristics & Yes & Yes & Yes & Yes & Yes & Yes \\
\hline Car characteristics & Yes & Yes & Yes & Yes & Yes & Yes \\
\hline Car model fixed-effects & Yes & No & Yes & No & Yes & No \\
\hline Macro controls & Yes & Yes & Yes & Yes & Yes & Yes \\
\hline Time trend & Yes & Yes & Yes & Yes & Yes & Yes \\
\hline State fixed-effects & Yes & Yes & Yes & Yes & Yes & Yes \\
\hline Observations & 17,349 & 17,349 & 17,349 & 17,349 & 17,349 & 17,349 \\
\hline Adjusted $R^{2}$ & 0.849 & 0.332 & 0.550 & 0.285 & 0.345 & 0.198 \\
\hline
\end{tabular}




\section{The Effect of the Law on Delinquency and Default}

This table reports results from regressing loan outcomes on law. We use three measures of loan outcomes: late payment, installment default, and default. All regressions include an intercept. The regressions control for contract terms (spread, maturity, and down payment), borrower characteristics (income, borrower type of risk, gender, presence of a guarantor, type of job, type of residence, marital status, and whether the borrower is a client of The Bank), car characteristics (a dummy for new car, car age, and dealer priority), macro variables (inflation, federal fund rate, quarterly GDP growth, and time trend), car model fixed-effects, and state fixed-effects. Standard errors are calculated by clustering at both the state and month levels. Variables definitions are provided in the Appendix. ***,**, and * denote statistical significance at the $1 \%, 5 \%$, and $10 \%$ levels, respectively.

\begin{tabular}{lccc}
\hline \hline $\begin{array}{l}\text { Dependent } \\
\text { Variable= }\end{array}$ & $\begin{array}{c}\text { late } \\
\text { payment }\end{array}$ & $\begin{array}{c}\text { installment } \\
\text { default }\end{array}$ & $\begin{array}{c}\text { loan } \\
\text { default }\end{array}$ \\
\hline Law & & & \\
& $0.015^{* *}$ & $0.014^{* *}$ & $0.015^{* *}$ \\
Contract terms & $(0.007)$ & $(0.007)$ & $(0.007)$ \\
Personal characteristics & Yes & Yes & Yes \\
Car characteristics & Yes & Yes & Yes \\
Car model fixed-effects & Yes & Yes & Yes \\
Macro controls & Yes & Yes & Yes \\
Time trend & Yes & Yes & Yes \\
State fixed-effects & Yes & Yes & Yes \\
Observations & Yes & Yes & 17,148 \\
Adjusted $R^{2}$ & & & 0.010 \\
\hline \hline
\end{tabular}


Table 10:

\section{The Effect of the Law on Delinquency and Default Stratified by Risk and Income}

This table reports results from regressing loan outcomes on law. We use three measures of loan outcomes: late payment, installment default, and default. Panel A stratifies the sample into low risk (odd columns) and high risk (even columns). Panel $\mathrm{B}$ stratifies the sample into low income (odd columns) and high income (even columns). Panel C stratifies the sample into low leverage (odd columns) and high leverage (even columns). All regressions include an intercept. The regressions control for contract terms (spread, maturity, and down payment), borrower characteristics (income, borrower type of risk, gender, presence of a guarantor, type of job, type of residence, marital status, and whether the borrower is a client of The Bank), car characteristics (a dummy for new car, car age, and dealer priority), macro variables (inflation, federal fund rate, quarterly GDP growth, and time trend), car model fixed-effects, and state fixed-effects. Standard errors are calculated by clustering at both the state and month levels. Variables definitions are provided in the Appendix. $* * *, * *$, and $*$ denote statistical significance at the $1 \%, 5 \%$, and $10 \%$ levels, respectively.

\begin{tabular}{|c|c|c|c|c|c|c|}
\hline \multicolumn{7}{|c|}{ Panel A: Stratified by risk } \\
\hline \multirow[t]{2}{*}{ Dependent Variable $=$} & \multicolumn{2}{|c|}{$\begin{array}{c}\text { late payment } \\
\text { risk }\end{array}$} & \multicolumn{2}{|c|}{$\begin{array}{c}\text { installment default } \\
\text { risk }\end{array}$} & \multicolumn{2}{|c|}{$\begin{array}{c}\text { loan default } \\
\text { risk }\end{array}$} \\
\hline & low & high & low & high & low & high \\
\hline \multirow[t]{2}{*}{ Law } & 0.009 & 0.017 & 0.008 & 0.017 & 0.009 & 0.017 \\
\hline & $(0.006)$ & $(0.095)$ & $(0.006)$ & $(0.095)$ & $(0.006)$ & $(0.095)$ \\
\hline Contract terms & Yes & Yes & Yes & Yes & Yes & Yes \\
\hline Personal characteristics & Yes & Yes & Yes & Yes & Yes & Yes \\
\hline Car characteristics & Yes & Yes & Yes & Yes & Yes & Yes \\
\hline Car model fixed-effects & Yes & Yes & Yes & Yes & Yes & Yes \\
\hline Macro controls & Yes & Yes & Yes & Yes & Yes & Yes \\
\hline Time trend & Yes & Yes & Yes & Yes & Yes & Yes \\
\hline State fixed-effects & Yes & Yes & Yes & Yes & Yes & Yes \\
\hline Observations & 12,623 & 464 & 12,623 & 464 & 12,623 & 464 \\
\hline Adjusted $R^{2}$ & 0.090 & 0.350 & 0.092 & 0.350 & 0.092 & 0.350 \\
\hline
\end{tabular}

Panel B: Stratified by income

\begin{tabular}{lcccccc} 
Dependent Variable= & \multicolumn{2}{c}{ late payment } & \multicolumn{2}{c}{$\begin{array}{c}\text { installment default } \\
\text { income }\end{array}$} & loan default \\
& low & high & low & high & low & high \\
\hline \multirow{2}{*}{ Law } & $0.024^{*}$ & 0.002 & $0.024^{*}$ & 0.001 & $0.023^{*}$ & 0.001 \\
& $(0.014)$ & $(0.011)$ & $(0.014)$ & $(0.010)$ & $(0.014)$ & $(0.001)$ \\
Contract terms & Yes & Yes & Yes & Yes & Yes & Yes \\
Personal characteristics & Yes & Yes & Yes & Yes & Yes & Yes \\
Car characteristics & Yes & Yes & Yes & Yes & Yes & Yes \\
Car model fixed-effects & Yes & Yes & Yes & Yes & Yes & Yes \\
Macro controls & Yes & Yes & Yes & Yes & Yes & Yes \\
Time trend & Yes & Yes & Yes & Yes & Yes & Yes \\
State fixed-effects & Yes & Yes & Yes & Yes & Yes & Yes \\
& & & & & & \\
Observations & 4,365 & 4,301 & 4,365 & 4,301 & 4,365 & 4,301 \\
Adjusted $R^{2}$ & 0.134 & 0.119 & 0.135 & 0.121 & 0.134 & 0.116 \\
\hline \hline
\end{tabular}

